\title{
Subcellular Localization of Bcr, Abl, and Bcr-Abl Proteins in Normal and Leukemic Cells and Correlation of Expression with Myeloid Differentiation
}

\author{
Meir Wetzler, * Moshe Talpaz, ** Richard A. Van Etten, ${ }^{5}$ Cheryl Hirsh-Ginsberg," Miloslav Beran, ${ }^{\star}$ and Razelle Kurzrock ${ }^{\star *}$ \\ Departments of *Clinical Investigation, Section of Biologic Studies, ${ }^{\ddagger}$ Hematology, and "Laboratory Medicine, University of Texas \\ M. D. Anderson Cancer Center, Houston, Texas 77030; and the ${ }^{\S}$ Center for Blood Research, Boston, Massachusetts 02115
}

\begin{abstract}
We used specific antisera and immunohistochemical methods to investigate the subcellular localization and expression of $\mathrm{Bcr}, \mathrm{Abl}$, and Bcr-Abl proteins in leukemic cell lines and in fresh human leukemic and normal samples at various stages of myeloid differentiation. Earlier studies of the subcellular localization of transfected murine type IV c-Abl protein in fibroblasts have shown that this molecule resides largely in the nucleus, whereas transforming deletion variants are localized exclusively in the cytoplasm. Here, we demonstrate that the murine type IV c-Abl protein is also found in the nucleus when overexpressed in a mouse hematopoietic cell line. However, in both normal and leukemic human hematopoietic cells, $\mathbf{c}-\mathbf{A b l}$ is discerned predominantly in the cytoplasm, with nuclear staining present, albeit at a lower level. In contrast, normal endogenous Bcr protein, as well as the aberrant $\mathrm{p}^{210^{B C R-A B L}}$ and p190 ${ }^{B C R-A B L}$ proteins consistently localize to the cytoplasm in both cell lines and fresh cells. The results with $210^{B C R-A B L}$ were confirmed in a unique $\mathrm{Ph}^{\mathbf{1}}$-positive chronic myelogenous leukemia (CML) cell line, KBM5, which lacks the normal chromosome 9 and hence the normal c-Abl product. Because the $210^{B C R-A B L}$ protein appears cytoplasmic in both chronic phase and blast crisis CML cells, as does the p190 ${ }^{B C R-A B L}$ in $\mathbf{P h}^{1}$-positive acute leukemia, a change in subcellular location of Bcr-Abl proteins between cytoplasm and nucleus cannot explain the different spectrum of leukemias associated with p210 and p190, nor the transition from the chronic to the acute leukemia phenotype seen in CML.

Further analysis of fresh CML and normal hematopoietic bone marrow cells reveals that $\mathrm{p}^{210^{B C R-A B L}}$, as well as the normal Bcr and Abl proteins, are expressed primarily in the early stages of myeloid maturation, and that levels of expression are reduced significantly as the cells mature to polymorphonuclear leukocytes. Similarly, a decrease in Bcr and Abl levels occurs in HL-60 cells induced by DMSO to undergo granulocytic differentiation. The action of $\mathbf{p 2 1 0}{ }^{B C R-A B L}$ and its normal counterparts may, therefore, take place during the earlier stages of myeloid development. (J. Clin. Invest. 1993. 92:1925-1939.) Key words: chronic myelogenous leukemia - hematopoiesis •
\end{abstract}

Address correspondence Meir Wetzler, M.D., University of Texas M. D. Anderson Cancer Center, Department of Clinical Investigation, Section of Biologic Studies, 1515 Holcombe Boulevard, Box 302, Houston, TX 77030.

Received for publication 20 January 1993 and in revised form 31 March 1993.

J. Clin. Invest.

(C) The American Society for Clinical Investigation, Inc.

$0021-9738 / 93 / 10 / 1925 / 15 \quad \$ 2.00$

Volume 92, October 1993, 1925-1939
Bcr-Abl fusion proteins $\bullet \mathrm{c}-\boldsymbol{A} B L$ protooncogene proteins $\bullet$ immunohistochemistry

\section{Introduction}

Clonal expansion of a hematopoietic stem cell containing a reciprocal translocation between chromosomes 9 and 22 (the Philadelphia translocation $\left.[\mathrm{Ph}]^{1}\right)$ characterizes chronic myelogenous leukemia (CML) and subsets of acute leukemia ( 1 , 2 ). This translocation results in the head-to-tail fusion of variable numbers of $5^{\prime}$ exons of the $B C R$ gene on chromosome 22 with the $\mathrm{c}-A B L$ gene derived from chromosome 9 (3-5). The resultant chimeric gene is transcribed into a hybrid $B C R-A B L$ mRNA in which exon 1 of $\mathrm{c}-A B L$ is replaced by $5^{\prime} B C R$ exons. $\mathrm{Bcr}-\mathrm{Abl}$ fusion proteins (p210 ${ }^{B C R-A B L}$ and $\mathrm{p} 190^{B C R-A B L}$ ) are produced; they contain the $\mathrm{NH}_{2}$-terminal 927 (or 902) or 426 amino acids of Bcr and are implicated in the development of CML and $\mathrm{Ph}^{1}$-positive acute leukemia, respectively $(3,6-9)$.

The oncogenic potential of the Bcr-Abl fusion proteins has been validated by their ability to transform hemopoietic progenitor cells in vitro (10-14). Furthermore, transgenic mice carrying $B C R-A B L$ constructs develop lymphoid tumors ( 15 , $16)$, and reconstituting lethally irradiated mice with bone marrow cells infected with retrovirus carrying the gene encoding $\mathrm{p} 210^{B C R \cdot A B L}$ leads to the development of several fatal hematopoietic neoplasms (17-19). By exploiting different retroviral constructs, a myeloproliferative syndrome resembling CML can be induced in $50 \%$ of the experimental animals; the remaining animals succumb to pre-B leukemia/lymphoma, or tumors of erythroid and macrophage cell types. Taken together, these data provide cogent evidence for $B C R-A B L$ gene participation in leukemogenesis.

Unfortunately, there still remain significant gaps in our understanding of the role of the normal $\mathrm{Abl}$ and $\mathrm{Bcr}$ proteins, as well as the aberrant $\mathrm{p} 210^{B C R-A B L}$ and $\mathrm{p} 190^{B C R-A B L}$ in human hematopoiesis. In this regard, two types of information might be relevant. First, the types of cells that express a particular protein might be informative. Yet, despite the presumed role of $\mathrm{Bcr}, \mathrm{Abl}$, and $\mathrm{Bcr}-\mathrm{Abl}$ in hematopoiesis, little is known about when these proteins are expressed during hematopoietic development. Second, subcellular localization of a protein often provides significant clues to its function, and the transition from the benign state to the fully malignant one might involve a change in subcellular residence. Importantly, such an event has been inferred from experiments with transfected mouse type IV c- $A B L$. The mammalian c- $A B L$ gene produces two proteins of $145 \mathrm{kD}$ that differ only at their $\mathrm{NH}_{2}$ terminus, denoted types I and IV c-Abl in mice, and types Ia and Ib c-Abl in

1. Abbreviations used in this paper: ALL, acute lymphoblastic leukemia; $\mathrm{CML}$, chronic myelogenous leukemia, $\mathrm{Ph}^{1}$, Philadelphia translocation. 
humans, respectively. As demonstrated by immunohistochemistry, the protein product of normal mouse type IV c- $A B L$ constructs transfected into fibroblasts resides mostly in the nucleus whereas constructs with a small $\mathrm{NH}_{2}$-terminal deletion produce a protein that has been moved to the cytoplasm and whose transforming potential has been fully activated (20). In this study, we have assessed the subcellular localization and differential expression of $\mathrm{Bcr}, \mathrm{Abl}$, and $\mathrm{Bcr}-\mathrm{Abl}$ proteins in $\mathrm{Ph}^{1}$-positive CML and acute lymphoblastic leukemia (ALL) cell lines, as well as in fresh leukemic and normal samples. We have also exploited a unique p210 ${ }^{B C R-A B L}$-positive CML line (KBM-5), which lacks the normal chromosome 9 and, hence, the normal c- $A B L$ product. Our observations suggest that normal endogenous $\mathrm{Bcr}$ protein, as well as the aberrant p210 ${ }^{B C R-A B L}$ and p190 ${ }^{B C R-A B L}$ localize to the cytoplasm in both cell lines and fresh cells. While the mouse type IV c-Abl protein resides mostly in the nucleus in hematopoietic cells and in fibroblasts, the majority of endogenous human c-Abl protein is found in the cytoplasm of hematopoietic cells and cell lines, though some nuclear staining is also present. In addition, a marked decrease in expression of Bcr and c-Abl is seen in the HL-60 leukemia cell line after induction of granulocytic differentiation. Analysis of fresh CML and normal hematopoietic cells reveals that $\mathrm{p} 210^{B C R-A B L}$ and the normal $\mathrm{Bcr}$ and $\mathrm{Abl}$ proteins are also expressed primarily in the early stages of myeloid maturation, and that levels of expression are reduced signifcantly as the cells differentiate.

\section{Methods}

Cell lines. We used the CML blastic crisis cell line K562 ( $\mathrm{Ph}^{1}$-positive), the promyelocytic leukemia cell line HL-60 ( $\mathrm{Ph}^{1}$-negative), the acute myelogenous leukemia cell line KG-1 ( $\mathrm{Ph}^{1}$-negative) (all obtained from American Type Culture Collection, Rockville, MD), the $\mathrm{Ph}^{1}$-positive acute lymphoblastic leukemia cell line ALL-1 (kindly provided by Dr. G. Rovera, Wistar Institute, Philadelphia, PA), a recently established $\mathrm{Ph}^{1}$-positive CML cell line designated KBM-5 (Beran, M., unpublished data) and $\mathrm{Ba} / \mathrm{F} 3$ cells (21), a B-lymphoid line that overexpresses the myristoylated form of mouse c-Abl (c-Abl type IV) (22) (generously provided by Dr. George Daley, Massachusetts General Hospital, Boston, MA). All cell lines except KBM-5 were cultured in RPMI 1640 (BioWhittaker, Walkersville, MD) containing 10\% inactivated fetal calf serum (Hyclone Laboratories, Logan, UT) in a $5 \% \mathrm{CO}_{2}$ incubator at $37^{\circ} \mathrm{C}$; the medium for $\mathrm{Ba} / \mathrm{F} 3$ cells was supplemented with $5 \%$ WEHI-3B conditioned medium as a source of interleukin-3. KBM5 cells were grown in Iscove's medium (GIBCO BRL, Grand Island, $\mathrm{NY}$ ) with $15 \%$ inactivated fetal calf serum.

Northern analysis. To evaluate the presence of $B C R, A B L$, and $B C R-A B L$ messages, total RNA was prepared as previously described (23). Poly $(\mathrm{A})^{+}$selected mRNA ( $4 \mu \mathrm{g} /$ lane) was then size-separated in $1.1 \%$ agarose/formaldehyde gels, transferred to nitrocellulose filters, and hybridized to ${ }^{32} \mathrm{P}$-labeled cDNA probes. Preparation of cDNA probes and hybridization conditions used for the Northern analysis have been previously described (24). The $B C R$ probe was derived from the $0.45 \mathrm{~kb}$ EcoR 1 / Pstl cDNA fragment located at the 5' end of clone $\mathrm{K} 28$. This fragment is composed entirely of non- $A B L$ sequences (25). The c- $A B L$ probe was derived from an EcoR1/BamHI cDNA fragment corresponding to the most $5^{\prime} \mathrm{v}-A B L$ hybridizing region (26).

Southern analysis. To evaluate the configuration of the $B C R$ gene, DNA was prepared, as previously described (27), and $10 \mu \mathrm{g}$ of DNA was digested with BamHI and BglII restriction endonucleases in conditions recommended by the supplier of the endonucleases (International Biotechnologies, Inc., New Haven, CT), electrophoresed in $0.8 \%$ agarose gel, blotted, and hybridized according to the method of Southern (28). The universal $B C R$ probe encompassing most of the
$5.8 \mathrm{~kb} B C R$ region (Phl/bcr-3) (Oncogene Science, Inc., Manhasset, NY) was labeled by oligoprimer extension to a specific activity of 1-3 $\times 10^{9} \mathrm{cpm} / \mu \mathrm{g}$ of DNA (29). After hybridization, the filters were washed at $60^{\circ} \mathrm{C}$ for $1 \mathrm{~h}$ in $0.1 \times \mathrm{SSC}$ solution $(\mathrm{SSC}=0.15 \mathrm{~mol} /$ liter sodium chloride, $0.015 \mathrm{~mol} /$ liter sodium citrate) containing $0.1 \%$ sodium dodecyl sulfate, dried, and autoradiographed.

$P C R$. Because cytogenetic analysis suggests that KBM-5 cells have lost their normal chromosome 9, we performed PCR to evaluate the presence of normal $A B L$ message in these cells. $1 \mu \mathrm{g}$ of total RNA was used for reverse transcription to cDNA and amplification reactions, as previously described (30), and the amplification was performed for 40 cycles. Detection was performed using the hybridization protection assay, according to methodology identical to that previously used in our laboratory ( 31 ). The $5^{\prime}$ primer was a 20 -mer beginning 65 bases upstream of the $\mathrm{c}-A B L$ exon Ib/II junction. The $3^{\prime}$ primer used is as previously described (30). An acridinium ester-labeled oligonucleotide complementary to $A B L$ exon Ib/II junction sequences was synthesized by Gen-Probe (San Diego, CA) (32). This probe is a 24-mer spanning the splice junction with 14 bases in exon II.

Similarly, to determine the presence of normal $B C R$ message in KBM-5 cells, we amplified normal $B C R$ cDNA using the following primers: BCRa 5'-AAGGCAGCCTTCGACGTCAATAAC-3', BCRb 5'-GACTTCGGTGGAGAACAGGATGCT-3'. Southern blotting and hybridization with an oligonucleotide probe 5'-ATTGACTGCCTCCTTCTCTGCCAC-3' was done for detection purposes according to the method of Kawasaki and colleagues (30).

Immune complex kinase assay. p210 ${ }^{B C R-A B L}$ and $\mathrm{p} 190^{B C R-A B L}$ were detected by exploiting their tyrosine phosphokinase enzymatic activity in the immune complex kinase assay (7). The antiserum used for this assay was anti-Abl389-403, a rabbit polyclonal serum made against the predicted hydrophilic domains of v-Abl (7). The immune complex kinase assay was performed on $2 \times 10^{7}$ cells. To ensure that the 210 and 190 bands on the gels represented proteins recognized by the anti-Abl serum, rather than background phosphorylation, alternate samples were incubated with anti-Abl serum and blocking cognate peptide $(7,33)$.

Fresh cells. Peripheral blood was obtained from five $\mathrm{CML} \mathrm{Ph}^{1} \mathrm{pa-}$ tients in the chronic phase of the disease, five patients at blast crisis, two individuals with acute myelogenous leukemia ( $\mathrm{Ph}^{1}$-negative), and three normal volunteers. In addition, two bone marrow samples derived from normal donors when marrow was collected for allogeneic transplant served as normal controls. Sample collections were performed at M. D. Anderson Cancer Center (Houston, TX) in accordance with institutional guidelines, and after obtaining informed consent from all participants. Red blood cells were lysed with $1.22 \%$ ammonium oxalate (Sigma Immunochemicals, St. Louis, MO), and the white blood cells were washed with PBS. To obtain blasts and granulocytes for immunoblotting, cells from a CML myeloid blast crisis patient were separated on Percoll (Pharmacia Fine Chemicals, Piscataway, $\mathrm{NJ}$ ) discontinuous gradient, and fractions 1.045 and $1.080 \mathrm{~g} / \mathrm{ml}$ were collected.

Immune reagents for immunofluorescence and immunohistochemistry. For detection of Abl protein, rabbit polyclonal antisera against $\mathrm{v}$-Abl trpE bacterial fusion protein pEX4 (kindly provided by Dr. Owen Witte, Howard Hughes Medical Institute, University of California at Los Angeles) was used (33). Soluble PEX4 protein for affinity purification of antisera and blocking purposes was obtained by expressing the PEX4 sequence as part of a bacterial fusion protein, with the Schistosoma japonicum gluthatione S-transferase protein in the glutagene expression system, as previously described $(20,34)$. For detection of Bcr protein, two antisera were used: $(a)$ rabbit polyclonal sera against $\beta$-galactosidase/Bcr fusion protein (35), which was affinitypurified using glutathione S-transferase Bcr fusion protein; and $(b)$ monoclonal antibody against $\mathrm{Bcr}$ (7C6), originally described by Dhut et al. (36) (Oncogene Science, Inc. Uniondale, NY). All these antisera have been extensively characterized (33-36).

Immunofluorescence. Cells were cytospun on glass slides at a density of $1 \times 10^{5}$ cells/slide. All subsequent steps were carried out at room 
temperature. Slides were fixed in $4 \%$ paraformaldehyde (Sigma Immunochemicals) in PBS for $10 \mathrm{~min}$. Paraformaldehyde fixed cells were quenched in 0.1 M 2-ethanolamine pH 8.0 (Sigma Immunochemicals) for $5 \mathrm{~min}$, then permeabilized by $0.2 \%$ Triton X-100 (Bio-Rad, Richmond, CA) in PBS for 10 min. Cells were then blocked with 5\% normal donkey serum (Jackson Immunoresearch Laboratories, West Grove, PA) for $30 \mathrm{~min}$. Primary antibodies were used at a 5-20 $\mu \mathrm{g} / \mathrm{ml}$ concentration. Where indicated, affinity purified anti-pEX4 antiserum was blocked with pEX4 fusion protein by incubation with a 10-fold molar excess of purified protein for $\mathbf{3 0} \mathrm{min}$ before application to cells. In all experiments, normal rabbit IgG (Jackson Immunoresearch Laboratories) was used as a negative control for anti-pEX4 sera and for the rabbit polyclonal anti-Bcr sera. Isotypic antibody was used as a control for the monoclonal anti-Bcr (7C6) sera. Incubation of primary antibody was for $45 \mathrm{~min}$, followed by extensive washing in PBS. The appropriate secondary antibody (Jackson Immunoresearch Laboratories) was added at a 1:100 dilution for $30 \mathrm{~min}$, after which the cells were washed briefly with PBS and mounted with $N$-propyl gallate (Sigma Immunochemicals). Conventional epifluorescence microscopy was performed with an Olympus Vanox AH-2 fluorescence microscope. Photography of fluorescence specimens was accomplished with Kodak Tmax ASA 400 black and white 35-mm film and Kodak Ektachrome ASA $800 / 1600$ color film.

Alkaline phosphatase staining. All steps were carried out at room temperature. Slides were fixed and treated as above. Alkaline phosphatase-tagged secondary antibodies (Jackson Immunoresearch Laboratories) were added at a 1:200-1:300 dilution. The alkaline phosphatase reagents (Dako Corp., Carpinteria, CA) were applied for $10 \mathrm{~min}$, after which the cells were washed briefly with water, counterstained with methyl green (Roboz Surgical Instrument Co., Inc., Washington, D.C.) for Abl and methylene blue (Fisher Scientific, Houston, TX) for Bcr, dehydrated, and mounted with Aqua-Mount (Lerner Laboratories, Pittsburgh, PA) or Permount (Fisher), respectively.

In vitro differentiation induction of $H L-60$ cells. To further dissect the expression of $\mathrm{Bcr}$ and $\mathrm{Abl}$ proteins in relation to the stage of differentiation, HL-60 cells were induced to undergo granulocytic differentiation by exposure to $1.25 \%$ dimethyl sulfoxide (37) in a $5 \% \mathrm{CO}_{2}$ incubator at $37^{\circ} \mathrm{C}$ for $5 \mathrm{~d}$. The cells were then cytospun and processed as described above for immunofluorescence reactions.

Western blotting. Immunoblotting was performed to further assess Bcr-Abl steady state protein levels. Briefly, our procedure was as follows: $2 \times 10^{7}$ lyophilized cells were lysed in Western sample buffer ( 10 mmol/liter Tris-HCL, $1 \mathrm{mmol} / 1$ EDTA, $1 \%$ SDS, 5\% glycerol, $1 \%$ $\beta$-mercaptoethanol, at final $\mathrm{pH}$ of 8.0 containing $0.1 \%$ bromo-phenolblue). Boiled and cleared lysates $(12,000 \mathrm{~g} \times 30 \mathrm{~min})$ were fractionated on $8 \%$ SDS-polyacrylamide gels. The fractionated proteins were transferred onto $0.1-\mu \mathrm{m}$ nitrocellulose membrane in $25 \mathrm{mM}$ Tris-HCL, 19 mM glycine, $0.1 \%$ SDS plus $20 \%$ methanol at $40 \mathrm{~V}$ overnight at $4^{\circ} \mathrm{C}$. The nitrocellulose blot was incubated with either rabbit anti-v-Abl sera or preimmune sera in TNE/NP-40 solution $(50 \mathrm{mmol} /$ liter Tris-HCL, $250 \mathrm{mmol} /$ liter $\mathrm{NaCl}, 2 \mathrm{mmol} / 1$ EDTA, $0.1 \%$ Nonidet $\mathrm{P}-40$ ) containing 3\% BSA (fraction 5; Sigma Immunochemicals) overnight. This sera was made by immunizing rabbits with a truncated product, $\mathrm{p} 160^{\mathrm{m}-A B L}$ of the Abelson murine leukemia virus. Complete details of the antisera have been previously published (38). The blot was rinsed with TNE/ NP-40 and then incubated with $0.2 \mu \mathrm{Ci}$ /lane of ${ }^{125}$ I-protein A (IM144; Amersham Corp., Arlington Heights, IL) in TNE/NP-40 containing $3 \% \mathrm{BSA}$ at $37^{\circ} \mathrm{C}$. After further washing with TNE/NP-40, the blot was autoradiographed using an intensifying screen at $-70^{\circ} \mathrm{C}$.

\section{Results}

Northern blot and polymerase chain reaction analysis of cell line $B C R, A B L$ and $B C R-A B L R N A$. Hybridization with c$A B L$ and $B C R$ cDNA probes revealed the characteristic $8.5-\mathrm{kb}$ $B C R-A B L$ mRNA in the two CML cell lines: K562 and KBM5. The normal 6- and 7-kb c- $A B L$ mRNA species were present

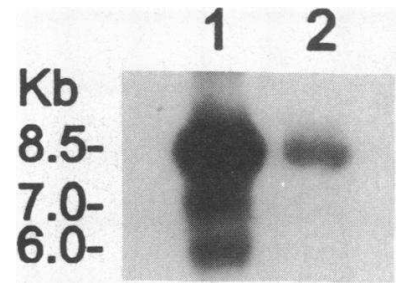

Figure 1. Northern blot of mRNA from $\mathrm{K} 562$ cells (lane 1 ) and KBM-5 cells (lane 2). The blot was hybridized with an EcoRI/ BamHI cDNA fragment corresponding to the most 5' v- $A B L$ hybridizing region (26).

in $\mathrm{K} 562$ cells (Fig. 1, lane 1) but not in KBM-5 cells (Fig. 1, lane 2). Likewise, PCR analysis followed by HPA did not detect the normal $A B L$ cDNA in KBM-5 cells (data not shown), confirming the absence of these sequences in KBM-5 cells; these data are consistent with the karyotypic analysis of KBM5 cells, which demonstrates loss of the normal chromosome 9 (39). PCR analysis did detect the normal $B C R$ cDNA sequence in KBM-5 cells (data not shown). (The cell line KBM5 was previously described to lack the normal $B C R$ gene based on the presence of only a rearranged $B C R$ band [without the germline ] on Southern blot of DNA hybridized with a $3^{\prime} 1$.2-kb HindIII/BglII $B C R$ genomic probe [ 39]. However, by hybridizing a Southern blot containing DNA from KBM-5 cells with the larger [ $5.8 \mathrm{~kb}$ ] universal $\mathrm{Ph} 1 / \mathrm{bcr}-3$ probe, we were able to show the presence of the germline $B C R$ DNA. These results suggest that a $3^{\prime} B C R$ sequence deletion has occurred in $\mathrm{KBM}$ 5 cells, accounting for the previously published results, and consistent with our observation of normal $B C R$ transcripts in this cell line.)

Immune complex kinase analysis of p210 ${ }^{B C R-A B L}$ and p190 ${ }^{B C R-A B L}$ proteins. The immune complex kinase assay can detect Abl-related proteins because they are enzymatically active as phosphokinases. In this assay, K562 and KBM-5 cells showed p210 ${ }^{B C R-A B L}$ whereas ALL-1 cells showed p190 ${ }^{B C R-A B L}$. HL-60 and KG-1 cells showed neither p210 ${ }^{B C R-A B L}$ nor p190 ${ }^{B C R-A B L}$ (Fig. 2). (The antiserum used for this assay was anti-Abl389-403 [7], and we have previously determined that this antibody is unable to detect the normal c-Abl protein $[40,41]$.)

p210 ${ }^{B C R-A B L}$ and $190^{B C R-A B L}$ are cytoplasmic in $\mathrm{Ph}^{\mathrm{I}}$-positive leukemic cell lines. The $\mathrm{Ph}^{1}$-positive human $\mathrm{CML}$ and ALL cell lines (K562 and ALL-1) express p210 ${ }^{B C R-A B L}$ and p190 ${ }^{B C R-A B L}$, respectively, at levels about 10 -fold greater than the normal c-Abl (as determined by Western blotting (Van Etten, R. A. and R. Kurzrock, unpublished data)) so that both anti-Abl and anti-Bcr antibodies predominantly detect $\mathrm{Bcr}-\mathrm{Abl}$ under the conditions we used (Figs. 3-5). K562 cells showed strong immunoreactions localized to the cytoplasm when the anti-pEX4 sera was used (Fig. $3 \mathrm{~A}$ ). Cytoplasmic localization of $\mathrm{p} 210^{B C R-A B L}$ was further confirmed by studying KBM-5 cells (Fig. $5 \mathrm{~A}$ ) (which lack the normal Abl product) eliminating the possibility of colocalization with the normal counterpart as a

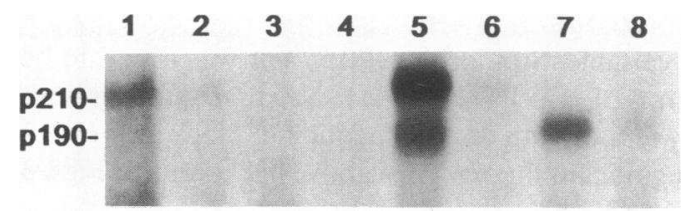

Figure 2. Immune complex kinase assay of KBM-5 cells (lanes 1 and 2), HL-60 cells (lanes 3 and 4), K562 cells (lanes 5 and 6), and ALL-1 cells (lanes 7 and 8). Antisera used was the anti Abl 389-403 (7). Even lanes were blocked with cognate peptide. 

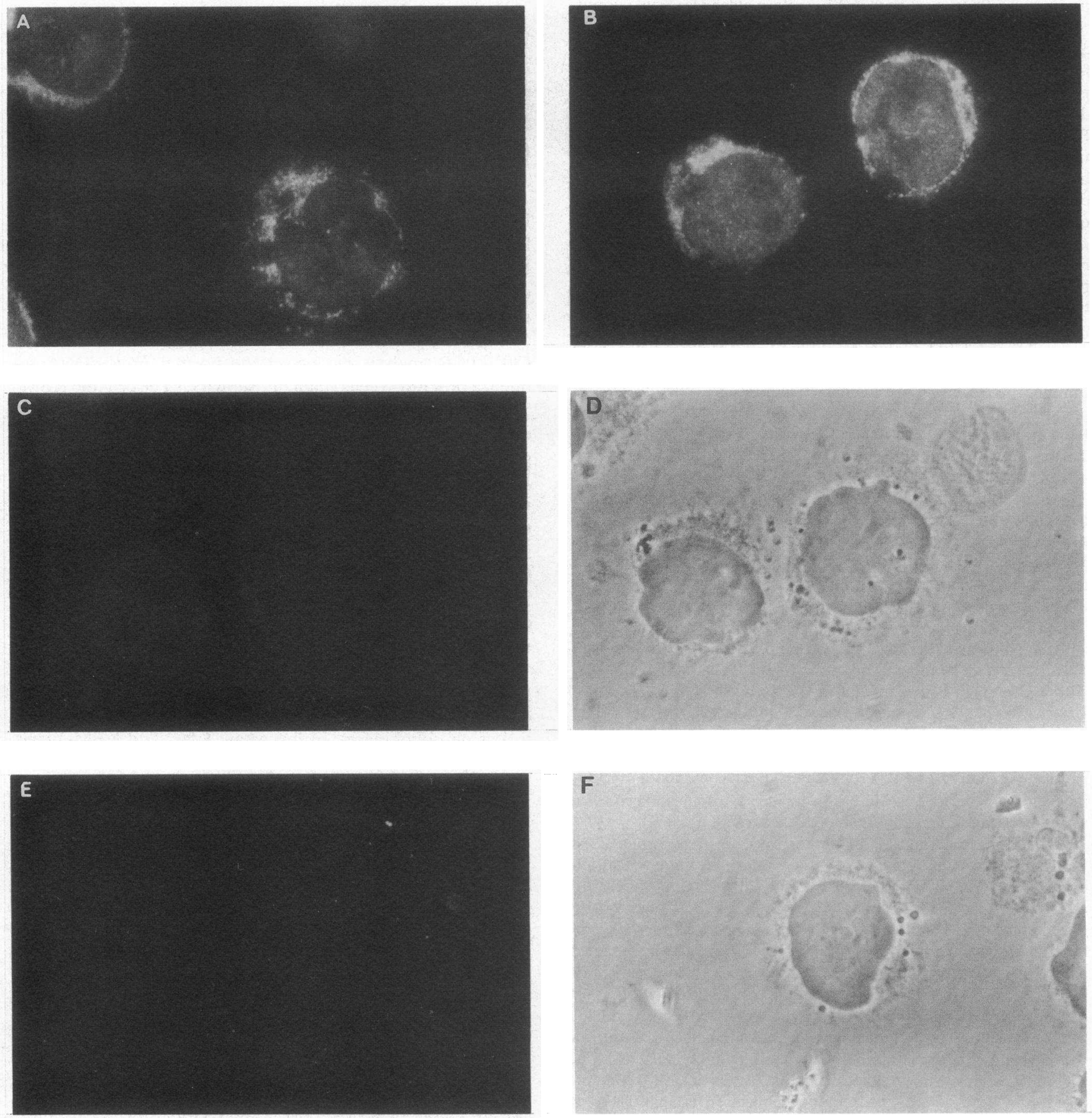

Figure 3. Indirect immunofluorescence of K562 cells. Primary antibodies were as follows: $(A)$ anti-pEX4 antibody directed against the Abl $\mathrm{COOH}$ terminus, $(B)$ rabbit polyclonal anti-Bcr antibody, $(C)$ normal rabbit $\operatorname{IgG},(D)$ phase contrast of $C ;(E)$ anti-pEX4 antibody preadsorbed with pEX4 fusion protein; and $(F)$ phase contrast of $E . \times 1,000$.

confounding variable. Similarly, p190 ${ }^{B C R-A B L}$ was found to be cytoplasmic in ALL-1 cells (Fig. $4 \mathrm{~A}$ ). Negative controls with normal rabbit sera or with cognate peptide to block anti-pEX4 sera gave no significant fluorescence above background (Figs. 3 $C$ and $E, 4 C$, and $5 C$ ).

Murine c-Abl type IV protein exhibits predominantly nuclear localization in a hematopoietic cell line. In the mouse $\mathrm{Ba} / \mathrm{F} 3$ cells that overexpress mouse $\mathrm{c}-\mathrm{Abl}$ type IV protein (the myristoylated form of c-Abl) (22), c-Abl was found predomi- nantly in the nucleus, (Fig. 6), but with some staining of the cytoplasm and with several cells exhibiting the prominent plasma membrane staining also seen with other myristoylated Abl proteins (22). Therefore, murine type IV c-ABL localization in the lymphoblastoid $\mathrm{Ba} / \mathrm{F} 3$ cells was similar to that previously shown for this protein in fibroblasts (20).

The c-Abl protein exhibits predominantly cytoplasmic localization in human leukemic cell lines. The $\mathrm{Ph}^{1}$-negative human myeloid leukemia cell lines (HL-60 and KG-1) demonstrated a 

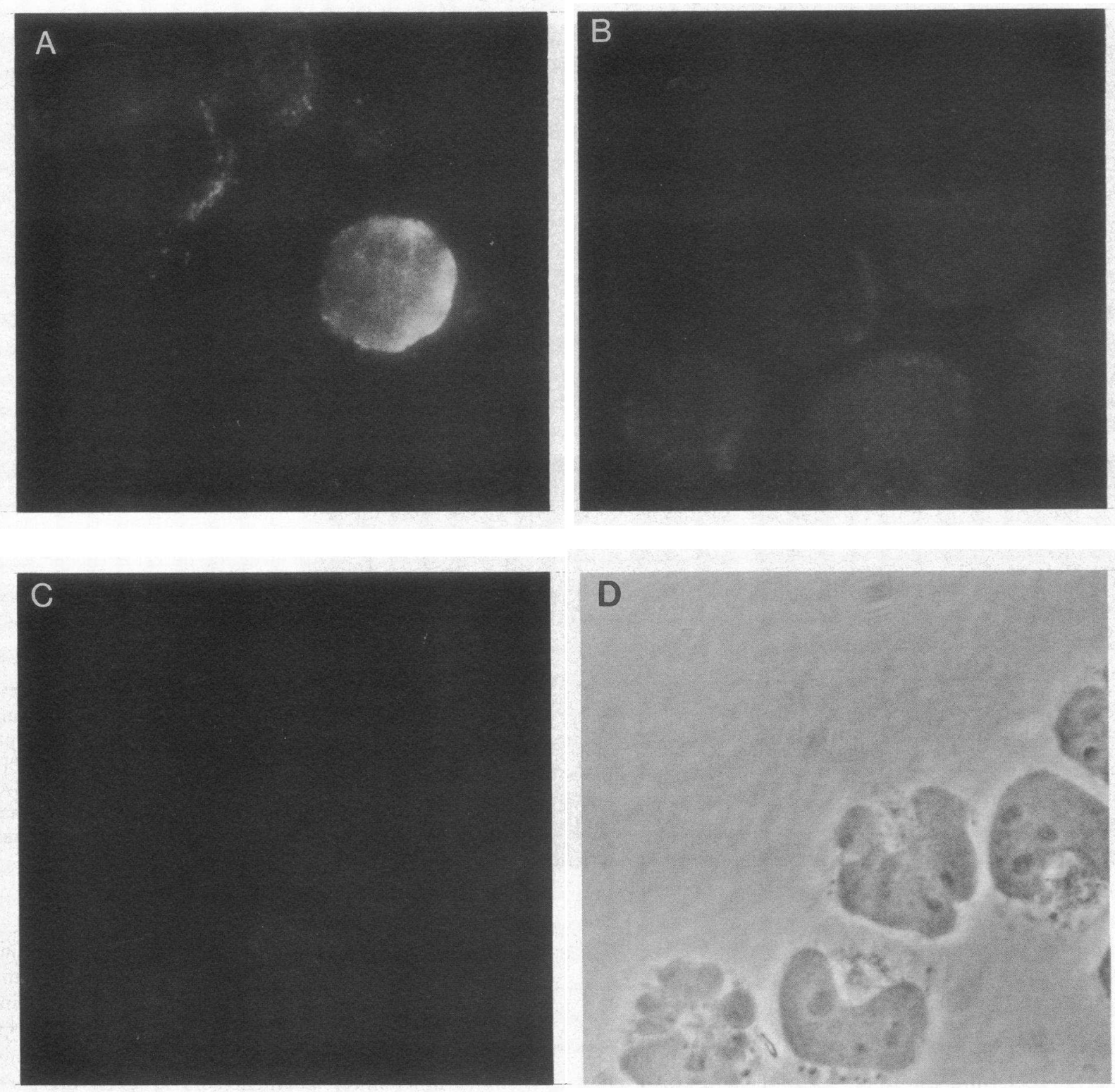

Figure 4. Indirect immunofluorescence of ALL-1 cells. Primary antibodies were as follows: $(A)$ anti-pEX4 antibody directed against the Abl $\mathrm{COOH}$ terminus, $(B)$ rabbit polyclonal anti-Bcr antibody, $(C)$ normal rabbit $\mathrm{IgG}$, and $(D)$ phase contrast of $C . \times 1,000$.

signal for c-Abl which localized, however, mainly to the cytoplasm, with nuclear staining present at a lower level (HL-60, Fig. 7; KG-1 data not shown).

The Bcr protein exhibits cytoplasmic localization in leukemic cell lines. The immunofluorescence reactions with the rabbit polyclonal anti-Bcr antibody revealed positive cytoplasmic signals for $\mathrm{Bcr}$ protein in $\mathrm{Ph}^{1}$-negative myeloid leukemic cell lines (HL-60 and KG-1) (Fig. 8). (In the Philadelphia-positive K562 and KBM-5 cell lines, the signals detected by this antisera were also cytoplasmic, but probably represent the p210 ${ }^{B C R-A B L}$ protein which is expressed at high levels [Figs. $3 B$ and $5 B$ ].) The p190 ${ }^{B C R-A B L}$-positive line (ALL-1) showed only a weakly positive cytoplasmic reaction (Fig. $4 B$ ). In the latter cell line, the anti-Bcr sera would be expected to discern only the normal Bcr protein, and not $\mathrm{p} 190^{B C R-A B L}$, since both of our anti-Bcr antibodies were raised against a $B C R$ region that is deleted from $\mathrm{p} 190^{B C R-A B L}(33,41)$. Control experiments with normal rabbit $\mathrm{IgG}$ demonstrated no significant fluorescence (Figs. $3 C, 4 C, 5 C$, and $8 B$ ). Thus, the normal Bcr protein is cytoplasmic in the $\mathrm{Ph}^{1}$-positive and $\mathrm{Ph}^{1}$-negative cell lines tested.

Detection of $c-A b l, B c r$, and Bcr-Abl proteins in fresh samples and correlation with myeloid differentiation. Using immunohistochemistry techniques and fresh $\mathbf{P h}^{1}$-positive $\mathrm{CML}$ cells, the anti-pEX4 Abl sera (Fig. 9, $C-E$ ), as well as the monoclonal anti-Bcr (7C6) reacted (Fig. 10,C and $D$ ), with decreasing intensity, as the cells progressed from myeloblasts and promyelocytes to myelocytes, metamyelocytes, and mature polymorphonuclear cells. Since CML cells express high levels of $\mathrm{p} 210^{B C R-A B L}$, and since both of these antisera detect this protein, these results suggest that the levels of $\mathrm{p} 210^{B C R-A B L}$ are higher in earlier stages of myeloid maturation. The signal for $\mathrm{Bcr}-\mathrm{Abl}$ was cytoplasmic in all of these cells, and there was no apparent change in subcellular localization as the disease pro- 

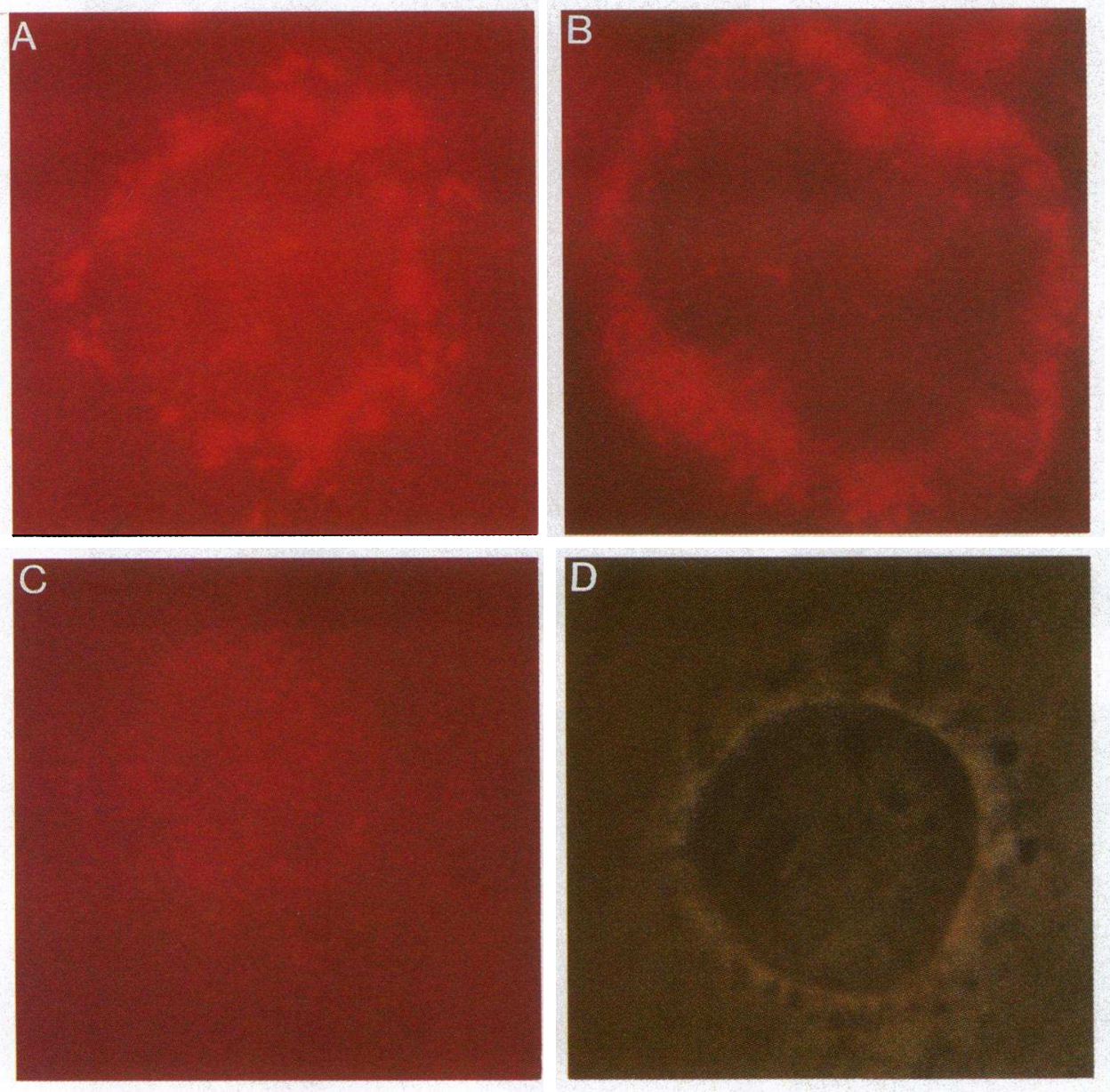

Figure 5. Indirect immunofluorescence of KBM-5 cells. Primary antibodies were as follows: $(A)$ anti-pEX4 antibody directed against the $\mathrm{Abl}$ $\mathrm{COOH}$ terminus; (B) rabbit polyclonal anti-Bcr antibody, $(C)$ normal rabbit $\mathrm{IgG}$, and $(D)$ phase contrast of C. $\times 1,000$.

gressed from chronic phase (Figs. 9, $C$ and $D$ and $10 C$ ) to blast crisis (Figs. $9 E$ and $10 \mathrm{D}$ ).

Samples derived from bone marrow of normal donors reflected the same pattern as CML cells i.e., the expression of c-Abl (Fig. $9 \mathrm{~A}$ ), as well as Bcr (Fig. $10 \mathrm{~A}$ ) at an early maturational stage, as determined with the use of the anti-pEX4 sera and the monoclonal anti-Bcr (7C6), respectively. However, there was a weaker signal than seen in CML samples. Cells derived from patients with $\mathrm{Ph}^{1}$-negative acute myelogenous leukemia ( 50-70\% blasts), also revealed weakly positive staining for c-Abl and Bcr solely in cells in the early myeloblastic stages (Figs. $9 \mathrm{~B}$ and $10 \mathrm{~B}$ ). No Abl or Bcr signal was detected in normal control peripheral blood samples which contain no immature myeloid cells (data not shown). The localization was predominantly cytoplasmic in all cells tested for both Bcr and c-Abl. In all experiments with fresh cells in which the antipEX4 sera was used, control experiments with cognate peptide for anti-pEX4 sera, as well as with normal rabbit sera demonstrated no significant signal. Similarly, in experiments in which the monoclonal anti-Bcr (7C6) was used, controls with isotypic antibody consistently demonstrated no significant reactions (data not shown).

To further confirm that a reduction in Bcr-Abl protein levels accompanied myeloid differentiation, immunoblotting was performed. Peripheral blood cells from a CML myeloid blast crisis patient were separated by Percoll gradient. The original sample contained $60 \%$ blasts, the fraction at $1.045 \mathrm{~g} / \mathrm{ml}$ con- tained $98 \%$ blasts, and the fraction at $1.080 \mathrm{~g} / \mathrm{ml}$ contained $92 \%$ neutrophils. As can be seen in Fig. 11, blast cells (lane 2) had considerable higher levels of $\mathrm{Bcr}-\mathrm{Abl}$ and $\mathrm{Abl}$ proteins as compared to unfractionated leukocytes (lane 1) or neutrophils (lane 3).

In vitro differentiation induction of $H L-60$ cells and correlation with the presence of $\mathrm{Bcr}$ and $\mathrm{Abl}$ proteins. Immunofluorescence techniques using anti-pEX4 sera and monoclonal antiBcr (7C6) sera, demonstrated that DMSO-induced granulocytic maturation of HL-60 cells was accompanied by a significant decrease in $\mathrm{Abl}$ and Bcr positivity, respectively (Fig. $12 A, B, D$, and $E$ ). Control experiments with normal rabbit IgG, and isotypic antibody, respectively, showed no significant fluorescence (data not shown).

\section{Discussion}

Subcellular localization of $p 210^{B C R-A B L}, p 190^{B C R-A B L}$, and the normal Bcr and $\mathrm{Abl}$ proteins. Abl belongs to a family of tyrosine protein kinase enzymes and, in general, these types of proteins are membrane receptors or cytoplasmic, with the latter presumed to function as signal transducing molecules. In humans, two alternative forms of the normal c-Abl protein exist (type $1 \mathrm{a}$ and $1 \mathrm{~b}$ ); they differ in their amino terminal 26 and 44 amino acids $(42,43)$. These proteins are highly homologous to the murine c-Abl type I and IV proteins, respectively (44). Structural and sequence analyses have revealed several 

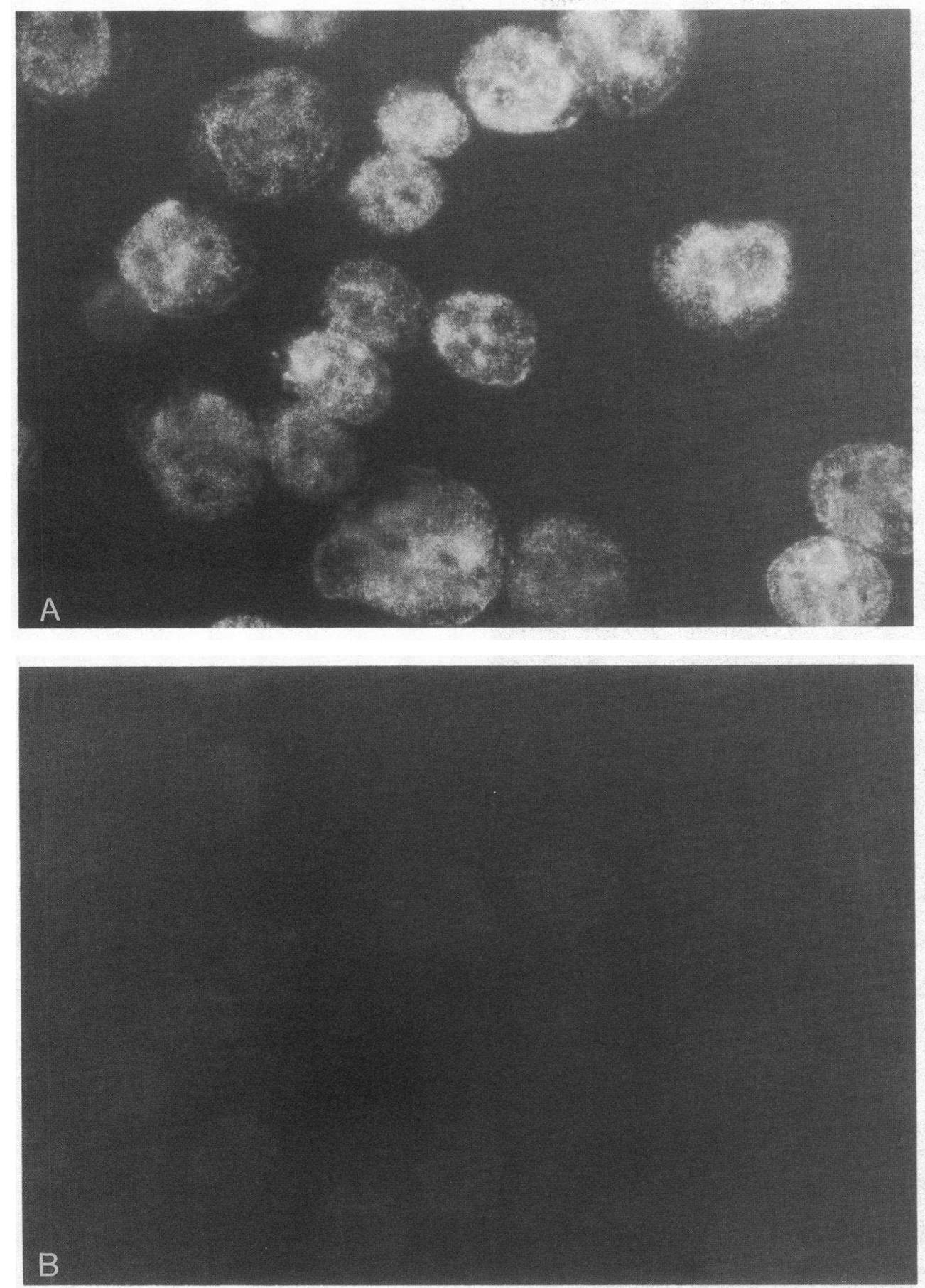

Figure 6. Indirect immunofluorescence of $\mathrm{Ba} / \mathrm{F} 3$ cells. Primary antibodies were as follows: $(A)$ anti$\mathrm{pEX} 4$ antibody directed against the $\mathrm{Abl} \mathrm{COOH}$ terminus and $(B)$ normal rabbit IgG. $\times 1,000$.

$\mathrm{NH}_{2}$ - and $\mathrm{COOH}$-terminal features that may provide clues to c-Abl subcellular localization and function. For instance, mouse c-Abl IV is myristoylated on the $\mathbf{N H}_{2}$-terminus, whereas c-Abl I is predicted not to be myristoylated (45). $\mathrm{Hu}$ man c-Abl $\mathbf{l b}$ also contains an $\mathrm{NH}_{2}$-terminus glycine residue and a putative myristoylation sequence. Attachment of the myristoyl moiety is involved in targeting cellular proteins to associate with the plasma membrane as exemplified by Gag$\mathrm{Abl}$ ( viral $\mathrm{Abl}$ ) proteins, which are $\mathrm{NH}_{2}$-myristoylated and distribute at least in part to the cellular membrane $(36,46,47)$. Other studies indicate that it is the carboxy-terminal of c-Abl that is critical in determining subcellular localization. This re- gion contains domains that confer on the mammalian c-Abl protein the ability to bind both DNA (potential nuclear localization) (48) and cytoskeletal actin microfilaments (potential cytoplasmic localization) $(20,49)$. In addition, the carboxy terminus of Drosophila Abl dictates proper localization to axons in central nervous system cells (50).

Recently, Van Etten and colleagues (20) have demonstrated that when the murine type IV c-Abl protein is overexpressed in NIH3T3 fibroblasts, it is found to be largely nuclear, with smaller amounts in cytoplasm, plasma membrane, and associated with the actin cytoskeleton. A $\mathrm{COOH}$-terminal motif that is unique to c-Abl and not found in Src or other tyrosine 

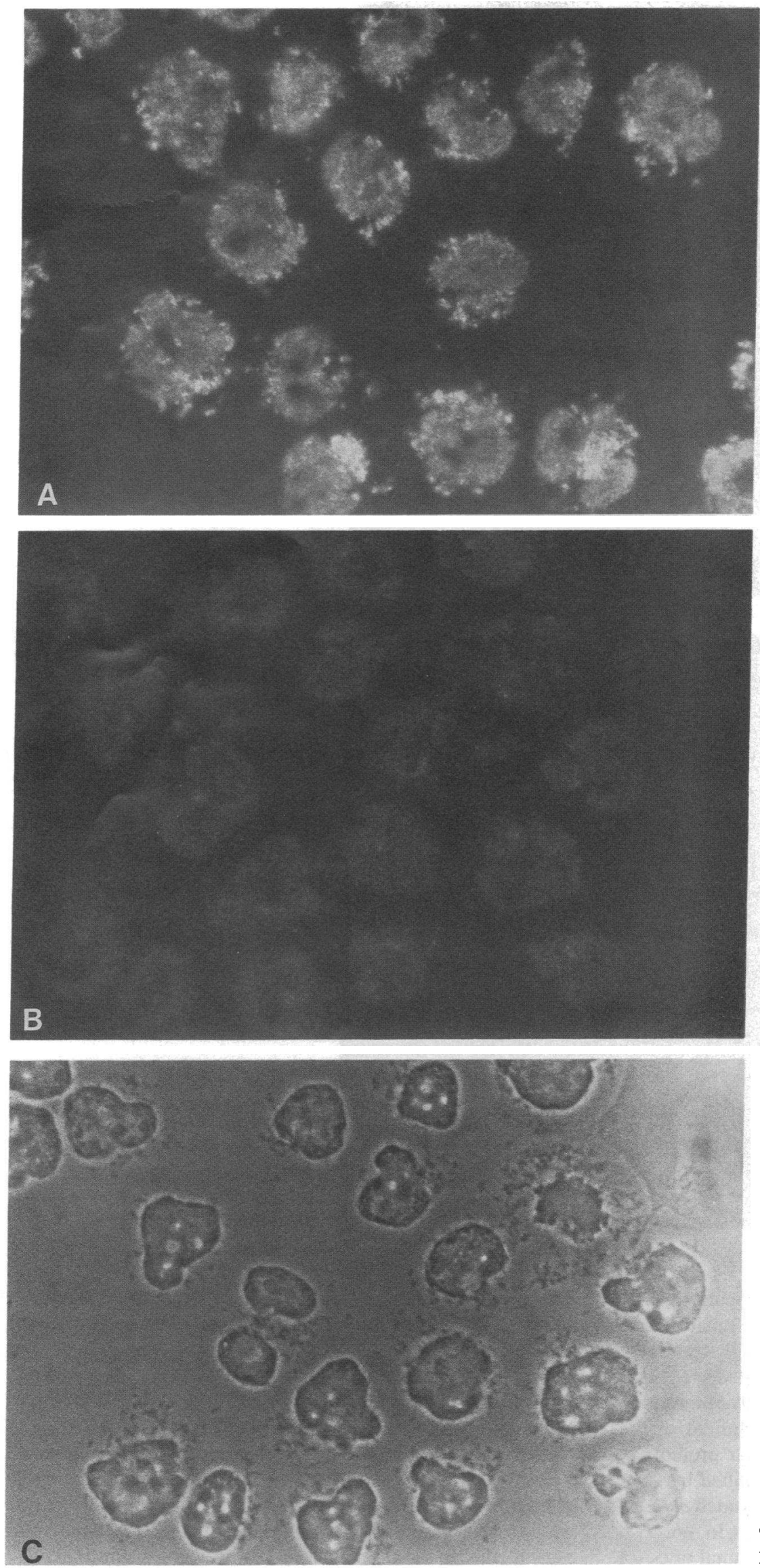

Figure 7. Indirect immunofluorescence of HL-60 cells. Primary antibodies were as follows: $(A)$ anti-pEX4 antibody directed against the $\mathrm{Abl}$ $\mathrm{COOH}$ terminus, $(B)$ normal rabbit $\mathrm{IgG}$, and $(C)$ phase contrast of $B . \times 1,000$. 

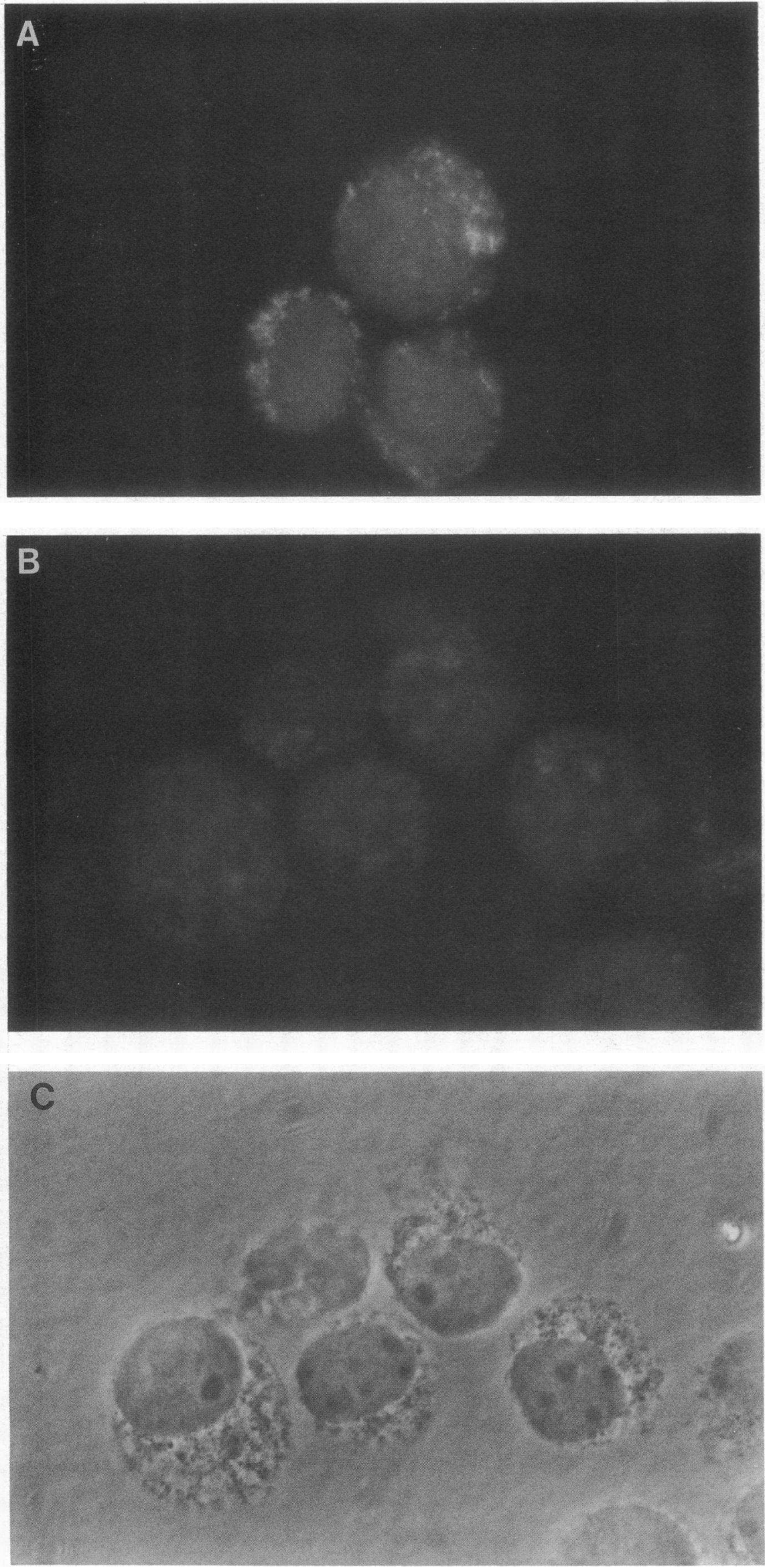

Figure 8. Indirect immunofluorescence of HL60 cells. Primary antibodies were as follows: $(A)$ rabbit polyclonal anti-Bcr antibody; $(B)$ normal rabbit $\operatorname{IgG}$, and $(C)$ phase contrast of B. $\times 1,000$. 

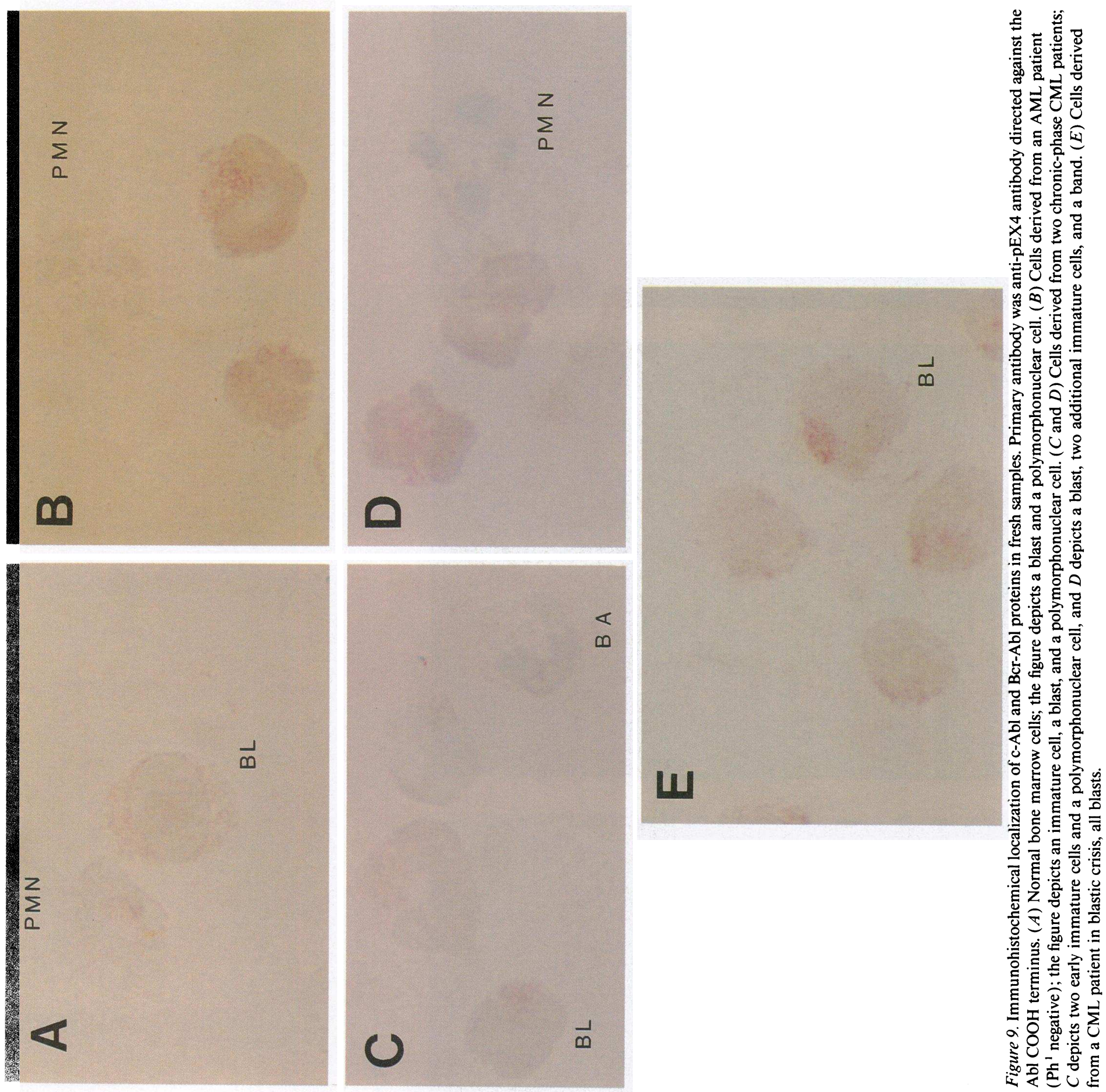

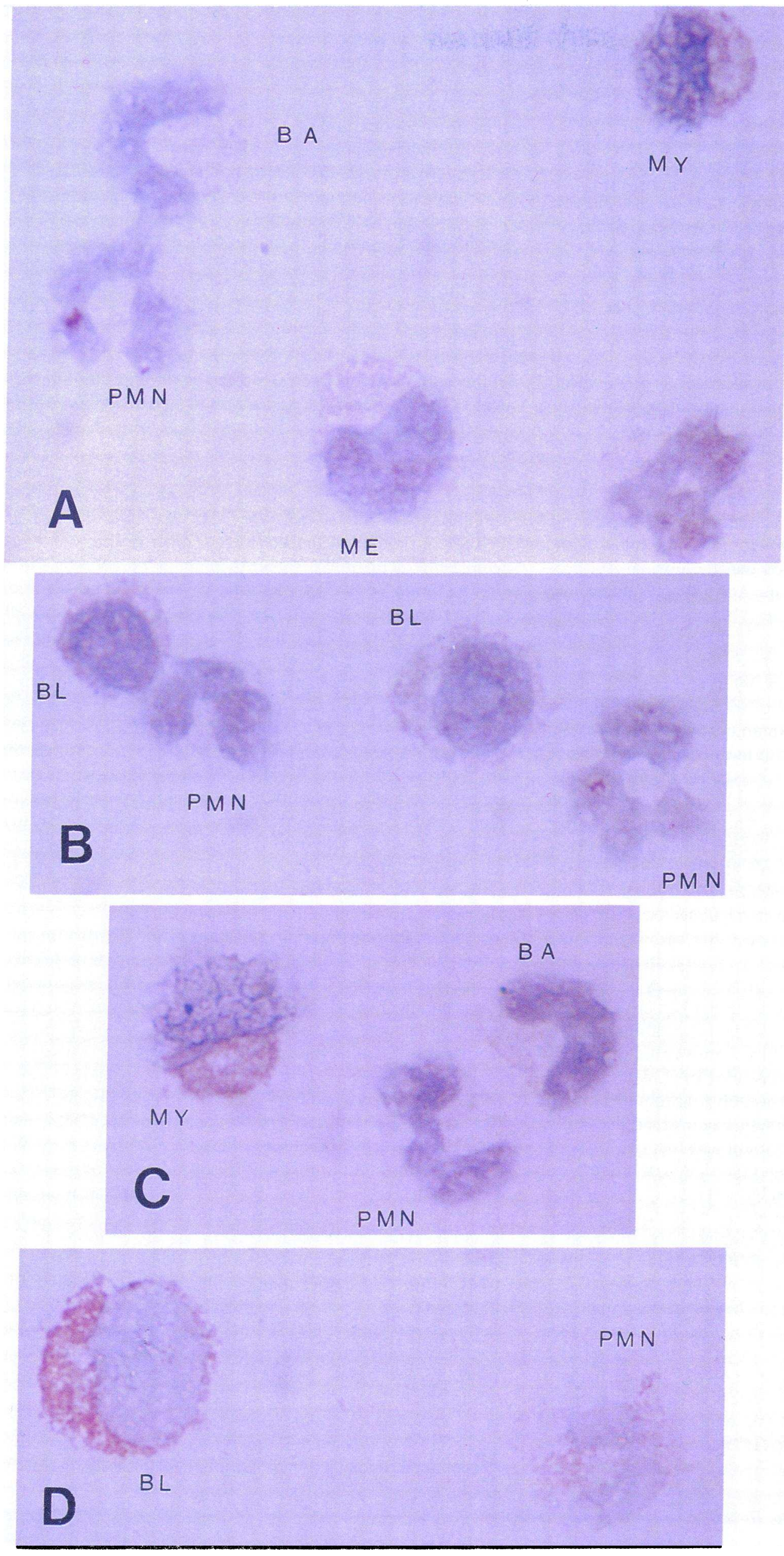

Figure 10. Immunohistochemical localization of Bcr and Bcr$\mathrm{Abl}$ proteins in fresh samples. Primary antibody was monoclonal anti-Bcr (7C6) antibody. ( $A$ ) Normal bone marrow cells; the figure depicts an immature cell, most probably a myelocyte, a metamyelocyte, a band, and a polymorphonuclear. ( $B$ ) Cells derived from an AML patient $\left(\mathrm{Ph}^{1}\right.$ negative $)$; the figure depicts two blasts and two polymorphonuclears. $(C)$ Cells derived from a chronic phase CML patient; the figure depicts a myelocyte, a band, and a mature polymorphonuclear. $(D)$ Cells derived from a CML patient in blastic crisis; the figure depicts a blast and a mature polymorphonuclear. 

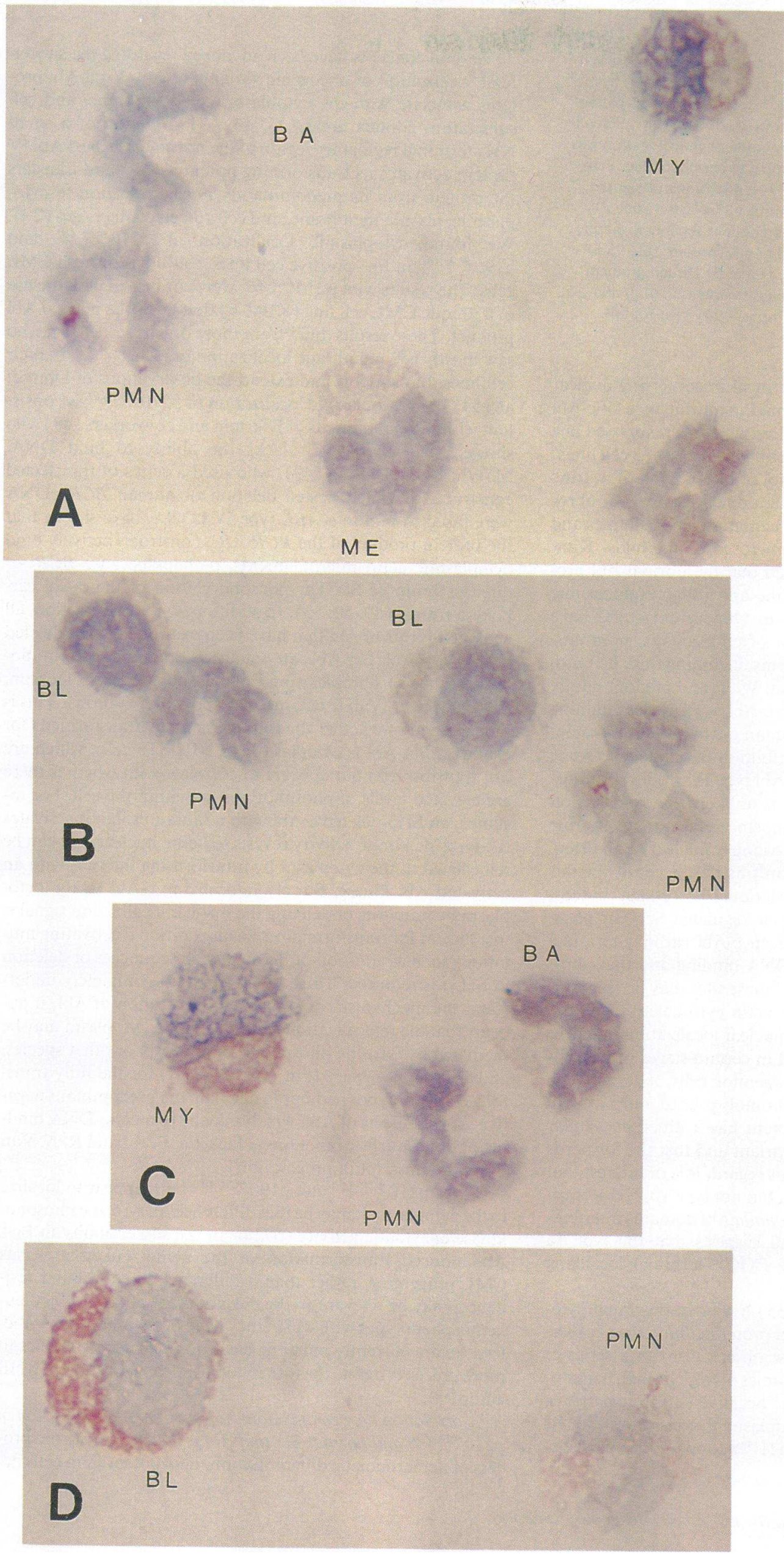

Figure 10. Immunohistochemical localization of Bcr and BcrAbl proteins in fresh samples. Primary antibody was monoclonal anti-Bcr (7C6) antibody. $(A)$ Normal bone marrow cells; the figure depicts an immature cell, most probably a myelocyte, a metamyelocyte, a band, and a polymorphonuclear. $(B)$ Cells derived from an AML patient ( $\mathrm{Ph}^{1}$ negative); the figure depicts two blasts and two polymorphonuclears. $(C)$ Cells derived from a chronic phase CML patient; the figure depicts a myelocyte, a band, and a mature polymorphonuclear. $(D)$ Cells derived from a CML patient in blastic crisis; the figure depicts a blast and a mature polymorphonuclear. 

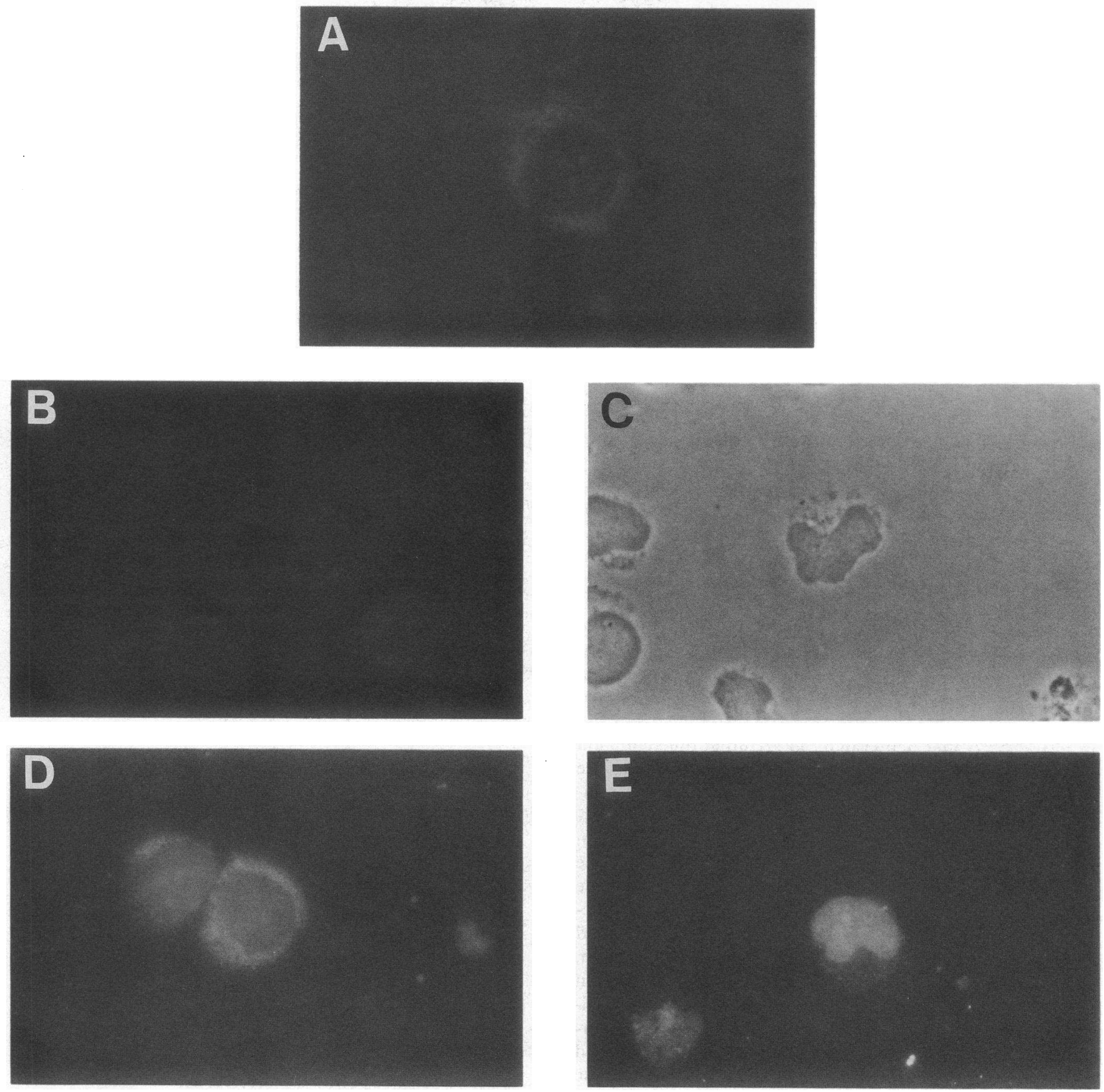

Figure 12. Indirect immunofluorescence of HL-60 cells induced by DMSO to undergo granulocytic differentiation. Primary antibodies were as follows: $(A-C)$ anti-pEX4 antibody directed against the Abl COOH terminus; $A$ depicts undifferentiated cells, $B$ shows DMSO-exposed differentiated cells, and $C$ depicts phase contrast of $B$. ( $D$ and $E$ ) Monoclonal anti-Bcr (7C6) antibody; $D$ shows undifferentiated cells, and $E$ depicts DMSO-exposed differentiated cells. $\times 1,000$. The secondary antibody against anti-Abl sera $(A-C)$ was rhodamine conjugated; no background fluorescence is seen with this fluorochrome. The secondary antibody used with anti-Bcr sera was fluorescein conjugated $(D$ and $E)$. Background fluorescence of the nucleus is seen with the use of this fluorochrome and is of the same intensity in cells exposed to anti-Bcr sera or control isotypic antibody (data not shown).

come lineage committed and eventually differentiate into functional, morphologically distinct end-stage cells. This process is accompanied by the coordinate expression of numerous genes. For example, sustained expression of $c-M Y B$ blocks the differentiation of Friend murine erythroleukemia cells (58), whereas a reduction of $\mathrm{c}-M Y B$ expression by specific antisense oligodeoxynucleotide blocks the proliferation of normal hu- man bone marrow mononuclear cells in progenitor colony culture assay (59), suggesting that c- MYB plays a role in controlling proliferation and differentiation of hematopoietic cells. Similarly, K562 cells express high levels of c-MYC and c- $M Y B$ mRNA; differentiation along the erythroid lineage induced by $1-\beta$-D-arabinofuranosylcytosine, daunomycin, or hemin is accompanied by a decrease in c- $M Y C$ and c-MYB transcript lev- 
els $(60,61)$. A decrease in c- $M Y C$ and c- $M Y B$ also accompanies myeloid differentiation of HL-60 cells (62) and a murine myeloid leukemic cell line (63). Thus, it seems that the downregulation of c- $M Y C$ and $c-M Y B$ mRNA may be a significant event in myeloid and erythroid maturation.

Little data exists regarding the role of $\mathrm{Bcr}$ and $\mathrm{Abl}$ proteins in hematopoiesis. Our observations indicate that the expression of both Bcr and Abl proteins among normal myeloid cells is inversely related to maturation; thus, myeloblasts and promyelocytes are highly positive for $\mathrm{Bcr}$ and $\mathrm{Abl}$ proteins, whereas polymorphonuclear cells are weakly positive. These findings have been substantiated by the in vitro differentiating experiments on HL- 60 cells. Their maturation toward the granulocytic pathway was accompanied by a decrease in Bcr and Abl protein levels.

$\mathrm{P} 210^{B C R-A B L}$ is also expressed at higher levels in immature myeloid CML cells than in more mature elements, but the signal appears stronger than that of normal $\mathrm{Abl}$ in normal bone marrow myeloid precursors, and does not disappear completely with full myeloid maturation. The mechanism by which both the Bcr-Abl, Bcr, and c-Abl proteins are down regulated upon differentiation of myeloid cells and cell lines is not known. This might occur at the transcriptional or posttranscriptional level. Bcr-Abl proteins are expressed off the normal Bcr promoter, so this might reflect the normal pattern of expression of this promoter. Interestingly, the same drop in P210 expression occurs upon differentiation to the metamyelocyte and neutrophil stage in CML mice, where P210 is expressed off a retroviral promoter, so this phenomenon might be of a more general nature (Van Etten, R. A., unpublished observation). Alternatively, previous experiments demonstrating a decrease in $\mathrm{p} 210^{B C R-A B L}$ after hemin-induced erythroid differentiation of $\mathrm{K} 562$ cells $(61,64)$ suggest a translational mechanism since $B C R-A B L$ mRNA remains unchanged. However, the relationship between erythroid differentiation of $\mathrm{K} 562$ cells and BcrAbl expression may be more complex, since the use of certain alternate differentiation agents such as cytosine arabinoside does not alter $\mathrm{p} 210^{B C R-A B L}$ levels (61). In regard to c-Abl, some antisense experiments (65) implicate a lineage-specific function of $\mathrm{c}-\mathrm{Abl}$ in myeloid development, so our findings would suggest that this action of $\mathrm{Abl}$ is quite early in differentiation. The presence of elevated levels of an aberrant Bcr-Abl protein (which is known to have a high constitutive tyrosine phosphokinase enzymatic activity) may, therefore, account for the discordant maturation (66) and resultant expansion of the myeloid compartment, which is the phenotypic hallmark of chronic phase CML.

\section{Acknowledgments}

We would like to acknowledge Dr. George Daley (Department of Medicine, Massachusetts General Hospital, Boston, MA) for the generous donation of the $\mathrm{Ba} / \mathrm{F} 3$ cell line overexpressing type IV c-Abl. R. A. Van Etten is supported by the Lucille P. Markey Charitable Trust, and he is a Lucille P. Markey Scholar.

\section{References}

1. Nowell, P. C., and D. A. Hungerford. 1960. A minute chromosome in human chronic granulocytic leukemia. Science (Wash. DC). 132:1497.

2. Rowley, J. D. 1973. A new consistent chromosomal abnormality in chronic myelogenous leukaemia identified by quinacrine fluorescence and Giemsa staining. Nature (Lond.) 243:290-293.
3. Kurzrock, R., J. U. Gutterman, and M. Talpaz. 1988. The molecular genetics of Philadelphia chromosome positive leukemias. N. Engl. J. Med. 319:990997.

4. Shtivelman, E., B. Lifshitz, R. P. Gale, and E. Canaani. 1985. Fused transcript of ABL and BCR genes in chronic myelogenous leukaemia. Nature (Lond.) 315:550-554.

5. ar-Rushdi, A., M. Negrini, R. Kurzrock, K. Huebner, and C. M. Croce. 1988. Fusion of the $b c r$ and $\mathrm{c}$-abl genes in $\mathrm{Ph}^{1}$-positive acute lymphocytic leukemia with no rearrangement in the breakpoint cluster region. Oncogene. 2:353357.

6. Konopka, J. B., S. M. Watanabe, and O. N. Witte. 1984. An alteration of the human $\mathrm{c}-a b l$ protein in $\mathrm{K} 562$ leukemia cells unmasks associated tyrosine kinase activity. Cell. 37:1035-1042.

7. Kloetzer, W., R. Kurzrock, L. Smith, M. Talpaz, M. Spiller, J. Gutterman, and $R$. Arlinghaus. 1985. The human cellular abl gene product in the chronic myelogenous leukemia cell line $\mathrm{K} 562$ has an associated tyrosine kinase activity. Virology. 140:230-238.

8. Kurzrock, R., M. Shtalrid, P. Romero, W. S. Kloetzer, M. Talpaz, J. M. Trujillo, M. Blick, M. Beran, and J. U. Gutterman. 1987. A novel c-abl protein product in Philadelphia-positive acute lymphoblastic leukaemia. Nature (Lond.). 325:631-635.

9. Chan, L. C., K. K. Karhi, S. I. Rayter, N. Heisterkamp, S. Eridani, R. Powles, S. D. Lawler, J. Groffen, J. G. Foulkes, M. F. Greaves, and L. M. Wiedemann. 1987. A novel $a b l$ protein expressed in Philadelphia chromosome positive acute lymphoblastic leukaemia. Nature (Lond.). 325:635-637.

10. McLauglin, J., E. Chianese, and O. N. Witte. 1987. In vitro transformation of immature hematopoietic cells by the P210 BCR/ABL oncogene product of the Philadelphia chromosome. Proc. Natl. Acad. Sci. USA. 84:6558-6562.

11. Young, J. C., and O. N. Witte. 1988. Selective transformation of primitive lymphoid cells by the BCR/ABL oncogene expressed in long-term lymphoid or myeloid cultures. Mol. Cell. Biol. 8:4079-4087.

12. Scherle, P. A., K. Dorshkind, and O. N. Witte. 1990. Clonal lymphoid progenitor cell lines expressing the $\mathrm{BCR} / \mathrm{ABL}$ oncogene retain full differentiative function. Proc. Natl. Acad. Sci. USA. 87:1908-1912.

13. Daley, G. Q., and D. Baltimore. 1988. Transformation of an interleukin 3-dependent hematopoietic cell line by the chronic myelogenous leukemia-specific P210 ${ }^{B C R / A B L}$ protein. Proc. Natl. Acad. Sci. USA. 85:9312-9316.

14. Hariharan, I. K., J. M. Adams, and S. Cory. 1988. BCR-ABL oncogene renders myeloid cell line factor independent: potential autocrine mechanism in chronic myeloid leukemia. Oncogene Res. 3:387-399.

15. Hariharan, I. K., A. W. Harris, M. Crawford, H. Abud, E. Webb, S. Cory, and J. M. Adams. 1989. A BCR-v-ABL oncogene induces lymphomas in transgenic mice. Mol. Cell. Biol. 9:2798-2805.

16. Heisterkamp, N., G. Jenster, J. ten Hoeve, D. Zovick, P. K. Pattengale, and J. Groffen. 1990. Acute leukaemia in BCR-ABL transgenic mice. Nature (Lond.). 344:251-253.

17. Elefanty, A. G., I. K. Hariharan, and S. Cory. 1990. BCR-ABL, the hallmark of chronic myeloid leukaemia in man, induces multiple haemopoietic neoplasms in mice. EMBO (Eur. Mol. Biol. Organ.) J. 9:1069-1078.

18. Kelliher, M. A., J. McLaughlin, O. N. Witte, and N. Rosenberg. 1990. Induction of a chronic myelogenous leukemia-like syndrome in mice with v-ABL and BCR/ABL. Proc. Natl. Acad. Sci. USA. 87:6649-6653.

19. Daley, G. Q., R. A. Van Etten, and D. Baltimore. 1990. Induction of chronic myelogenous leukemia in mice by the $P 210^{B C R / A B L}$ gene of the Philadelphia chromosome. Science (Wash. DC). 247:824-830.

20. Van Etten, R. A., P. Jackson, and D. Baltimore. 1989. The mouse type IV $\mathrm{c}$ - $a b l$ gene product is a nuclear protein, and activation of transforming ability is associated with cytoplasmic localization. Cell. 58:669-678.

21. Palacios, R., and M. Steinmetz. 1985. IL-3 dependent mouse clones that express B-220 surface antigen, contain Ig genes in germ-line configuration, and generate B lymphocytes in vivo. Cell. 41:727-730.

22. Daley, G. Q., R. A. Van Etten, P. K. Jackson, A. Bernards, and D. Baltimore. 1992. Nonmyristoylated Abl proteins transform a factor-dependent hematopoietic cell line. Mol. Cell. Biol. 12:1864-1871.

23. Chirgwin, J. M., A. E. Przybyla, R. J. MacDonald, and W. J. Rutter. 1979. Isolation of biologically active ribonucleic acid from sources enriched in ribonuclease. Biochemistry. 18:5294-5299.

24. Thomas, P. S. 1980. Hybridization of denatured RNA and small DNA fragments transferred to nitrocellulose. Proc. Natl. Acad. Sci. USA. 77:52015205.

25. Groffen, J., J. R. Stephenson, N. Heisterkamp, A. de Klein, C. R. Bartram, and G. Grosveld. 1984. Philadelphia chromosomal breakpoints are clustered within a limited region, bcr, on chromosome 22. Cell. 36:93-99.

26. de-Klein, A., A. G. Van Kessel, G. Grosveld, C. R. Bartram, A. Hagemeijer, D. Bootsma, N. K. Spurr, N. Heisterkamp, J. Groffen, and J. R. Stephenson. 1982. A cellular oncogene is translocated to the Philadelphia chromosome in chronic myelogenous leukemia. Nature (Lond.). 300:765-767.

27. Wong-Staal, F., M. S. Reitz, and R. C. Gallo. 1979. Retrovirus sequences in a leukemic gibbon and its contact: evidence for partial provirus in the nonleukemic gibbon. Proc. Natl. Acad. Sci. USA. 76:2032-2036. 
28. Southern, E. M. 1975. Detection of specific sequences among DNA fragments separated by gel electrophoresis. J. Mol. Biol. 98:503-517.

29. Feinberg, A. D., and B. Vogelstein. 1984. A technique for radiolabeling DNA restriction endonuclease fragments to high specific activity. Addendum. Anal. Biochem. 137:266-267.

30. Kawasaki, E. S., S. S. Clark, M. Y. Coyne, S. D. Smith, R. Champlin, O. N. Witte, and F. P. McCormick. 1988. Diagnosis of chronic myeloid and acute lymphocytic leukemias by detection of leukemia-specific mRNA sequences amplified in vitro. Proc. Natl. Acad. Sci. USA. 85:5698-5702.

31. Dhingra, K., M. Talpaz, M. G. Riggs, P. S. Eastman, T. Zipf, S. Ku, and R. Kurzrock. 1991. Hybridization protection assay: a rapid, sensitive, and specific method for detection of Philadelphia chromosome-positive leukemias. Blood 77:238-242.

32. Arnold, L. J. Jr., P. W. Hammond, W. A. Wiese, and N. C. Nelson. 1989. Assay formats involving acridinium-ester-labelled DNA probes. Clin. Chem. 35:1588-1594.

33. Konopka, J. B., R. L. Davis, S. M. Watanabe, A. S. Ponticelli, L. SchiffMaker, N. Rosenberg, and O. N. Witte. 1984. Only site-directed antibodies reactive with the highly conserved $s r c$-homologous region of the v-abl protein neutralize kinase activity. $J$. Virol. 51:223-232.

34. Smith, D., and K. S. Johnson. 1988. Single-step purification of polypeptides expressed in Escherichia coli as fusions with glutathione S-transferase. Gene (Amst.). 67:31-40.

35. Ben-Neriah, Y., G. Q. Daley, A.-M., Mes-Masson, O. N. Witte, and D. Baltimore. 1986. The chronic myelogenous leukemia-specific p210 protein is the product of the bcr/abl hybrid gene. Science (Wash. DC). 233:212-214.

36. Dhut, S., T. Chaplin, and B. D. Young. 1990. BCR-ABL and BCR proteins: Biochemical characterization and localization. Leukemia (Basingstoke) 4:745-750.

37. Collines, S. J., F. W. Ruscetti, R. E. Gallagher, and R. C. Gallo. 1978 Terminal differentiation of human promyelocytic leukemia cells induced by dimethyl sulfoxide and other polar compounds. Proc. Natl. Acad. Sci. USA. 75:2458-2462.

38. Ferguson, B., M. L. Pritchard, J. Feild, D. Reitman, R. G. Greig, G. Poste, and $\mathrm{M}$. Rosenberg. 1985. Isolation and analysis of an Abelson murine leukemia virus-encoded tyrosine-specific kinase produced in Escherichia coli. J. Biol. Chem. 260:3652-3657.

39. Blick, M., P. Romero, M. Talpaz, R. Kurzrock, M. Shtalrid, B. Andersson, J. Trujillo, M. Beran, and J. U. Gutterman. 1987. Molecular characteristics of chronic myelogenous leukemia in blast crisis. Cancer Genet. Cytogenet. 27:349-356.

40. Kurzrock, R., M. Shtalrid, M. Talpaz, W. S. Kloetzer, and J. U. Gutterman. 1987. Expression of $\mathrm{c}-\mathrm{ABL}$ in Philadelphia-positive acute myelogenous leukemia. Blood. 70:1584-1588.

41. Kurzrock, R., W. S. Kloetzer, M. Talpaz, M. Blick, R. Walters, R. B. Arlinghaus, and J. U. Gutterman. 1987. Identification of molecular variants of p210 bcr-abl in chronic myelogenous leukemia. Blood. 70:233-236.

42. Fainstein, E., M. Einat, E. Gokkel, C. Marcelle, C. M. Croce, R. P. Gale, and E. Canaani. 1989. Nucleotide sequence analysis of human $a b l$ and $b c r-a b l$ cDNAs. Oncogene Res. 4:1477-1481.

43. Shtivelman, E., B. Lifshitz, R. P. Gale, B. A. Roe, and E. Canaani. 1986. Alternative splicing of RNAs transcribed from the human $a b l$ gene and from the $b c r-a b l$ fused gene. Cell. 47:277-284.

44. Ben-Neriah, Y., A. Bernards, M. Paskind, G. Q. Daley, and D. Baltimore. 1986. Alternative 5 ' exons in $c$-abl mRNA. Cell. 44:577-586.

45. Jackson, P., and D. Baltimore. 1989. N-terminal mutations activate the leukemogenic potential of the myristoylated form of c-abl. EMBO (Eur. Mol. Biol. Organ.) J. 8:449-456.

46. Watanabe, S. M., N. E. Rosenberg, and O. N. Witte. 1984. A membrane- associated, carbohydrate-modified from the $\mathrm{v}$-abl protein that cannot be phosphorylated in vivo or in vitro. J. Virol. 51:620-627.

47. Rohrschneider, L. R., and L. M. Najita. 1984. Detection of the v-abl gene product at cell-substratum contact sites in Abelson murine leukemia virus-transformed fibroblasts. J. Virol. 51:547-552.

48. Dikstein, R., D. Heffetz, Y. Ben-Neriah, and Y. Shaul. 1992. c-abl has a sequence-specific enhancer binding activity. Cell. 69:751-757.

49. McWhirter, J. R., and J. Y. J. Wang. 1991. Activation of tyrosine kinase and microfilament-binding functions of $c-a b l$ by $b c r$ sequences in $b c r / a b l$ fusion proteins. Mol. Cell. Biol. 11:1553-1565.

50. Henkemeyer, M., S. R. West, F. B. Gertler, and F. M. Hoffmann. 1990. A novel tyrosine kinase-independent function of drosophila $a b l$ correlates with proper subcellular localization. Cell. 63:949-960.

51. Kitazawa, S., S. Maeda, and T. Sugiyama. 1990. Immunocytochemical evaluation of abl-gene products in leukemic cell lines. Med. Oncol. Tumor Pharmacother. 7:35-41.

52. Kipreos, E. T., and J. Y. J. Wang. 1992. Cell cycle-regulated binding of c-Abl tyrosine kinase to DNA. Science (Wash. DC). 256:382-385.

53. Kipreos, E. T., and J. Y. J. Wang. 1990. Differential phosphorylation of $\mathrm{c}$-Abl in cell cycle determined by $c d c 2$ kinase and phosphatase activity. Science (Wash. DC). 248:217-220.

54. Dhut, S., T. Chaplin, and B. D. Young. 1991. Normal c-abl gene protein-a nuclear component. Oncogene. 6:1459-1464.

55. Dhut, S., E. L. Dorey, M. A. Horton, T. S. Ganesan, and B. D. Young. 1988. Identification of two normal $b c r$ gene products in the cytoplasm. Oncogene. 3:561-566.

56. Diekmann, K., S. Brill, M. D. Garrett, N. Totty, J. Hsuan, C. Monfries, C. Hall, L. Lim, and A. Hall. 1991. BCR encodes a GTPase activating protein for p21 ${ }^{\mathrm{rac}}$. Nature (Lond.). 351:400-402.

57. Lugo, T. G., A-M. Pendergast, A. J. Muller, and O. N. Witte. 1990. Tyrosine kinase activity and transformation potency of $b c r-a b l$ oncogene, products. Science (Wash. DC). 247:1079-1082.

58. Clarke, M. F., J. F. Kukowska-Latallo, E. Westin, M. Smith, and E. V. Prochownik. 1988. Constitutive expression of a c-myb cDNA blocks Friend murine erythroleukemia cell differentiation. Mol. Cell. Biol. 8:884-892.

59. Gewirtz, A. M., and B. Calabretta. 1988. A c-myb antisense oligodeoxynucleotide inhibits normal human hematopoiesis in vitro. Science (Wash. DC) 242:1303-1306.

60. Tonini, G. P., D. Radzioch, A. Gronberg, M. Clayton, E. Blasi, G. Benetton, and L. Varesio. 1987. Erythroid differentiation and modulation of c-myc expression induced by antineoplastic drugs in the human leukemic cell line K562. Cancer Res. 47:4544-4547.

61. Eisbruch, A., M. Blick, M. J. Evinger-Hodges, M. Beran, B. Andersson, J. U. Gutterman, and R. Kurzrock. 1988. Effect of differentiation-inducing agents on oncogene expression in a chronic myelogenous leukemia cell line. Cancer (Phila.). 62:1171-1178.

62. Filmus, J., and R. N. Buick. 1985. Relationship of c-myc expression to differentiation and proliferation of HL-60 cells. Cancer Res. 45:822-825.

63. Gonda, T. J., and D. Metcalf. 1984. Expression of $m y b$, myc, and fos protooncogenes during the differentiation of a murine myeloid leukemia. Nature (Lond.). 310:249-251.

64. Richardson, J. M., A. O. Morla, and J. Y. J. Wang. 1987. Reduction in protein tyrosine phosphorylation during differentiation of human leukemia cell line K562. Cancer Res. 47:4066-4070.

65. Caracciolo, D., M. Valtieri, D. Venturelli, C. Peschle, A. M. Gewirtz, and B. Calabretta. 1989. Lineage-specific requirement of c-abl function in normal hematopoiesis. Science (Wash. DC). 245:1107-1110.

66. Strife, A., and B. Clarkson. 1988. Biology of chronic myelogenous leukemia: is discordant maturation the primary defect? Semin Hematol. 25:1-19. 